\title{
Agronomic potentials of quality protein maize hybrids developed in Ghana
}

\author{
P. Y. K. SALLAH, S. TWUMASI-AFRIYIE, K. AHENKORA, E. A. ASIEDU, K. OBENG-ANTWI, S. \\ OSEI-YEBOAH, P. P. FRIMPONG-MANSO, A. ANKOMAH \& B. D. DZAH \\ CSIR-Crops Research Institute, P. O. Box 3785, Kumasi, Ghana
}

\begin{abstract}
A quality protein maize (QPM) hybrid programme was started in 1991 to develop and promote high and stableyielding QPM hybrids to increase production of nutritionally superior maize varieties in Ghana. Six 3way QPM hybrids developed from inbred lines originating from germplasm of the International Centre for Maize and Wheat Improvement (CIMMYT) were evaluated on research stations and in farmers' fields in Ghana from 1995 to 1996. In the on-station evaluations, grain yields across 10 sites in both years averaged 6.0 ton $\mathrm{ha}^{-1}$ for the three hybrids (GH132-28, GH110-5 and GH2328-88), 5.22 ton $\mathrm{ha}^{-1}$ for Obatanpa, and 3.60 ton $\mathrm{ha}^{-1}$ for the local maize variety. In farmers' fields, data from over 50 farm sites in 1995 and 1996 showed mean yields of 4.95 ton $\mathrm{ha}^{-1}$ for the three hybrids, and 4.28 ton $\mathrm{ha}^{-1}$ for Obatanpa compared to 3.59 ton ha-1 for farmers' varieties. On the average, the hybrids were similar to Obatanpa in days to 50 per cent silking, but were shorter in plant height and ear placement. Consumer preference tests showed that the three hybrids were rated similar to the local variety in popular traditional food preparations such as 'kenkey' and 'tuo zafi'. In 1997 the National Variety Release Committee approved the release of GH132-28, GH110-5, and GH2328-88 under the local names Dadaba, Mamaba, and CIDA-ba, respectively. These hybrids are recommended for planting in all the major agro-ecologies to boost maize production in Ghana.
\end{abstract}

Original scientific paper. Received 16 Aug 05; revised 27 Mar 06.

\begin{abstract}
RÉSUMÉ
Sallah, P. Y. K., Twumasi-Afriyie, S., Ahenkora, K., Asiedu, E. A., Obeng-Antwi, K., Osei-Yeboah, S., Frimpong-Manso, P. P., Anкоман, A. \& Dzah, B. D.: Potentiels agronomiques de hybrides de maïs protéique de qualité développes au Ghana. Les variétés de maïs hybride (Zea mays L.) dont les plus sésirées que les variétés de pollinisation libre à cause de leur uniformté et leurs potentiels de rendement plus élevés. Pour augmenter la production de variétés de maïs nutritionnellement supérieures au Ghana, I'Institut de Recherche de Cultures a mis en place un programme hybrid de maïs protéique de qualité (MPQ) en 1991 pour développer et promouvoir des hybrides de MPQ de rendement élevés et stable. Six hybrids en trois de MPQ développés d'issu de la même souch provenant de germeplasmes de CIMMYT (Centre International pour I'amélioration de maïs et de blé) étaient évalués aux stations de recherches et aux champs d'agriculteurs au Ghana de 1995 à 1996. Dans les évaluations sur place, les rendements de grain à travers 10 sites dans les deux années ont atteint la moyenne de 6.0 ton ha ${ }^{-1}$ pour les trois hybrids (GH132-28, GH110-5 et GH2328-88), 5.22 ton ha-1 pour 'Obatanpa' et 3.60 ton ha ${ }^{-1}$ pour la variétés de maïs local. Sur les champs d'agriculteurs des données de plus que 50 sites de champs en 1995 et 1996 montraient les rendements moyens de 4.95 ton $\mathrm{ha}^{-1}$ pour les trois hybrids et 4.28 ton ha ${ }^{-1}$ pour les 'Obatanpa' comparées à 3.59 ton $\mathrm{ha}^{-1}$ pour les variétés d'agriculteurs. En moyenne, les hybrides étaient semblables à 'Obatanpa' en jours jusqu à $50 \%$ d'apparition de soie maïs étaient plus courtes en taille de plante et en placement d'épi. Les essais de préférence de consommateur montraient que les trios hybrides étaient évalués semblables à la variété locale dans les préparations de nouriture traditionnelle populaire telle que 'kenkey' et 'tuo zafi'. En 1997, le comité pour la mise en vente de Variété Nationale a approuvé la mise en vente de GH132-28, GH110-5 et GH2328-88 sous les noms locaux respectifs de Dadaba, Mamaba, et CIDA-ba. Ce hybrides sont recommandés pour la popultion dans toutes les agroéclogies majeures pour stimuler la production de maïs au Ghana.
\end{abstract}




\section{Introduction}

The development of hybrid maize is an outstanding technological success of the century (Tolessa et al., 1996). Hybrid maize genetics show that vigour is reduced as a result of inbreeding and vigour restored on crossing inbred parents (Sprague \& Dudley, 1988). In 1926, Henry Wallace of Pioneer Hybrid International produced and sold the first hybrid maize in the USA. Today, average hybrid maize yields in the USA are over $7.0 \mathrm{t} \mathrm{ha}^{-1}$, with some farmers recording up to $20 \mathrm{t} \mathrm{ha}^{-1}$. Soon, even higher yields will be realized because the maize plant is a very efficient system that can use environmental resource for yield increase (Sprague \& Dudley, 1988).

Zimbabwe was the first country in the world to release a single-cross hybrid for commercial production. And starting nearly from zero in 1930, by 1990 all the maize production in the country was reported to have come from hybrid seed (Lopez-Pereira \& Fillippello, 1995). The maize breeding programme of Zimbabwe evolved through the stages of open-pollinated varieties, double-cross hybrids, single-cross hybrids, topcross hybrids, and modified single-cross hybrids (Machida, 1996). Kenya and Ethiopia are other African countries in which improved hybrids developed by national maize-breeding programmes have been adopted by most largescale commercial and small subsistence farmers.

Recognizing the high and stable yields associated with hybrid maize development, the Crops Research Institute (CRI) started hybrid maize development in 1986. Maize variety development in Ghana in the past concentrated on developing open-pollinated maize varieties because of socio-economic reasons (TwumasiAfriyie et al., 1997). These included constraints such as lack of efficient seed production and distribution system, poor road infrastructure, and expected higher cost of hybrid seed. Early efforts were aimed at developing three-way normal maize hybrids and testing single and three-way hybrids developed by the International Centre for Maize and Wheat Improvement (CIMMYT), Mexico
(Twumasi-Afriyie et al., 1997). Although some promising normal maize hybrids were identified (Badu-Apraku, Sallah \& Twumasi-Afriyie, 1991), further efforts to test them on farmers' fields produced inconclusive results. Single crosses from the international centres could not be recommended by performance over the existing composite varieties in Ghana.

A quality protein maize (QPM) development programme in Ghana started in 1989 at the main stations of the CRI at Kwadaso and Fumesua in the forest region of Ghana, with collaboration from the Nyankpala Agricultural Experiment Station (NAES) (Twumasi-Afriyie et al., 1994a, 1994b, 1994c). This programme led to the release of an open-pollinated variety, Obatanpa, which has been widely adopted in Ghana (Twumasi-Afriyie et al., 1992, 1994b). The release of Obatanpa generated wide interest in QPM, leading to requests for the variety from several countries in Africa and elsewhere. While developing Obatanpa, a QPM hybrid programme was concurrently started in 1991 to develop highyielding, widely adapted, fertilizer-responsive hybrid varieties that are resistant to important diseases and insect pests.

This study aimed to determine the yield potentials of elite QPM three-way hybrids in the major agro-ecological zones of Ghana, and to identify the best hybrid variety for release to farmers.

\section{Materials and methods}

Several inbred lines were developed from QPM Populations 63 (tropical, intermediate white dent QPM) and 62 (tropical, intermediate white flint) collected from CIMMYT. Some inbred lines were screened under artificial streak pressure to identify those with resistance to the maize streak virus disease (Twumasi-Afriyie et al., 1994b). A QPM population, GH8363 SR, was used to topcross to several of the inbred lines to determine their combining ability (TwumasiAfriyie et al., 1994b). After the topcross evaluation in 1991, inbreeding was pursued 
continuously to obtain genetic and morphological homogeneity. The inbred lines were then combined in all possibilities in pairs to identify inbred lines with the best specific and general combining abilities. These were evaluated widely at experiment stations of CRI and SARI in the major agro-ecological zones of Ghana. Variety evaluations were organised into preliminary hybrid, advanced hybrid, station variety, on-farm variety, and international trials. Hybrid varieties were progressively eliminated based on performance, and only the most promising ones were advanced into the next testing stage.

The evaluations led to the selection of six hybrids, technically named GH110-5, GH110-88, GH132-28, GH110-28, GH2328-88 and GH2823140T. These were simultaneously tested in farmers' fields in Ghana and in an international QPM trial offered by the CRI Maize Programme in 1995 and 1996 (Twumasi-Afriyie et al., 1997). The on-farm test sites were in the Forest, Transition, Coastal Savanna and Guinea Savanna. The international test locations were in Benin, Nigeria, Ivory Coast and Guinea in West Africa; Zimbabwe and South Africa in southern Africa; Tanzania in East Africa; Congo in Central Africa; Guatemala and Mexico in Central America; and Brazil in South America. There were 10 entries in the trial, which consisted of eight medium-maturing varieties developed in Ghana comprising six QPM threeway hybrids, Obatanpa (QPM open-pollinated) and Abeleehi (normal non-QPM maize openpollinated), plus two checks nominated by cooperating scientists. The cooperators were asked to use two leading varieties under production in their area as the local checks.

In the international testing, a randomized complete block design with four replications was used. Randomization was completed at CRI and seed packets were marked with appropriate plot numbers. Seed packets were filled and serially arranged in the order they were to be planted in the field. Four empty envelopes for each of the two local check varieties were included in the package for the trial. Seeds were treated with
Marshal 25 ST (a red, powdery systemic insecticide with carbofuran as an active ingredient), and the same quantity of the insecticide was placed in each empty seed envelope for the check varieties.

Each plot consisted of four rows, with each row being $5.0 \mathrm{~m}$ long. The between-row spacing was $75 \mathrm{~cm}$. Two plants per hill were maintained at a spacing of $45 \mathrm{~cm}$ between hills, resulting in plant density of 53,333 plants ha ${ }^{-1}$ (GGDP, 1996). Data were collected from the two central rows of each plot, following standard procedures. The data collected included plant stand, number of days that 50 per cent of plants in a plot extruded silk, plant height, ear height, root and stalk lodging, score of husk tip-cover tightness, grain moisture at harvest, ear-aspect and field weight of grain at harvest. Major diseases were scored at each location, following standardized procedures. Details of experimental procedures were collected from cooperators and any differences reported were considered in the analyses.

Seven maize varieties-GH110-5, GH132-28, GH2328-88 (QPM hybrids); Obatanpa (QPM open-pollinated); NAES EE W-SR, Dorke SR (both improved normal maize); and Local variety (normal maize)-were processed into 'tuo zafi' (TZ), Ga and Fanti 'kenkey'. The foods were prepared by the staff of WIAD-MOFA and local food producers. For each food, 20 sensory evaluation panelists, who were producers or consumers or both, evaluated the varieties. The panelists rated the samples for overall acceptability (taste, texture, appearance) by how much they liked or disliked each sample. The rating was converted to scores on a seven-point hedonic scale: like very much $=7$, like moderately $=6$, like slightly $=$ 5 , neither like nor dislike $=4$, dislike slightly $=3$, dislike moderately $=2$, dislike very much $=1$. Data were analyzed using ANOVA, and Duncan's Multiple Range Test (DMRT) was applied to determine significance between sample means.

\section{Results}

Table 1 shows the names and some characteristics 
of maize varieties tested in local and international trials during the period 1994-1996. The results of on-station evaluation at six locations in 1994 showed that the three hybrids GH132-28, GH1105 and GH2328-88 produced grain yields of 5600, 5500 and $4900 \mathrm{~kg} \mathrm{ha}^{-1}$, respectively, compared with $4300 \mathrm{~kg} \mathrm{ha}^{-1}$ for Obatanpa and $3000 \mathrm{~kg} \mathrm{ha}^{-1}$ for the local variety (Table 2 ). The three hybrids were 19-28 and 29-38 per cent more productive than Obatanpa and Abeleehi, respectively. In 1995, the mean grain yield over 10 locations (Fumesua and Kwadaso in the Forest zone; Pokoase and Ohawu in the Coastal Savanna zone; Ejura and Kpeve in the Transition zone; Nyankpala,

TABLE 1

Names and Some Characteristics of Varieties Tested On-station, On-farm, and in International Trials Conducted During the Period 1994-1996

\begin{tabular}{llll}
\hline Variety \# & Varietal type & Parental source & Grain type* \\
\hline GH2328-140T & QPM 3-way Hybrid & CIMMYT Pop. 62, 63 & WF \\
GH110-28 & QPM 3-way Hybrid & Pop. 62, 63 & WFD \\
GH110-5 & QPM 3-way Hybrid & Pop. 62, 63 & WF \\
Obatanpa & QPM OPV & GH8363 SR & WD \\
GH110-88 & QPM 3-way Hybrid & CIMMYT Pop. 62, 63 & WFD \\
GH2328-88 & QPM 3-way Hybrid & CIMMYT Pop. 62, 63 & WFD \\
GH132-28 & QPM 3-way Hybrid & Population 62 & WFD \\
Abeleehi & Normal Maize OPV & CIMMYT Pop. 49 & WD \\
Local Check-1 & Normal Maize OPV & Landrace & WFD \\
Local Check-2 & Normal Maize OPV & Landrace & WFD \\
\hline
\end{tabular}

$* \mathrm{~W}=$ White $\quad \mathrm{F}=$ Flint $\quad \mathrm{D}=$ Dent $\quad \mathrm{OPV}=$ Open pollinated variety

\# All named varieties possessed resistance to the maize streak virus disease

TABLE 2

Grain Yield of Medium-maturing Maize Varieties Evaluated at Six Locations* During 1994 Major Season

\begin{tabular}{lcc}
\hline Variety & $\begin{array}{c}\text { Yield } \\
\left(\mathrm{kg} \mathrm{ha}^{-1}\right)\end{array}$ & $\begin{array}{c}\text { Yield } \\
(\% \text { Obatanpa })\end{array}$ \\
\hline GH110-5 & 5557 & 128 \\
GH132-28 & 5468 & 126 \\
GH2328-88 & 4852 & 119 \\
EV 8163 SR & 4609 & 106 \\
Obatanpa & 4335 & 100 \\
Aburotia & 4325 & 100 \\
Aburotia SR & 4307 & 99 \\
Abeleehi & 3902 & 90 \\
Local & 3006 & 69 \\
\hline Mean & 4603 & \\
LSD (0.05) & 487 & \\
CV (\%) & 19 & \\
\hline
\end{tabular}

* Kwadaso, Pokoase, Kpeve, Ejura, Nyankpala, and Kwadaso
Damongo and Yendi in the Guinea Savanna zone; and Manga in the Savanna zone) of the three hybrids GH110-5, GH132-28 and GH2328-88 were 7300,6800 and $6300 \mathrm{~kg} \mathrm{ha}^{-1}$, respectively (Table $3)$. In 1996, the three hybrids produced grain yields of 5200 to $5300 \mathrm{~kg} \mathrm{ha}^{-1}$ compared with 4600 $\mathrm{kg} \mathrm{ha}^{-1}$ for Obatanpa and $3100 \mathrm{~kg} \mathrm{ha}^{-1}$ for the local. The hybrids yielded 15-18 per cent higher than Obatanpa. Generally, differences in grain yield among the hybrids were not significant.

Two of the hybrids, GH132-28 and GH110-5, were tested in the 120-day On-Station Variety Trial that also included several normal (non-QPM) maize hybrids in 1995 and 1996. In both years, the QPM hybrids were the most productive in the trials and out-yielded the normal (non-QPM) hybrids and Okomasa, improved normal maize (Table 4). The advantage in grain yield over Okomasa was 12-23 per cent in 1995 and 8-15 per cent in 1996.

Combined analysis of trials in over 50 farms in 
collaboration with field staff of CRI, SARI and MOFA as well as cooperating farmers in 1995 and 1996 showed that the three hybrids were again more productive than Obatanpa and farmers' varieties. The three hybrids were $12-20$ per cent higher yielding than Obatanpa (Table 5). The difference in grain yield was even greater when the hybrids were compared with the farmers' variety in both years. Plant and ear heights of GH110-5 were the shortest among the hybrids (Table 6). Both GH13228 and GH2328-88 had similar plant height as Obatanpa. For maturity ratings, the hybrids flowered in 57, 53 and 53 days, respectively, compared with 55 by Obatanpa; indicating that they had intermediate maturity periods.

Mean grain yield over eight locations in four West African countries ranged from 3200 to $4900 \mathrm{~kg} \mathrm{ha}^{-1}$ (Table 7). Four QPM hybrids GH110-5, GH110-88, GH132-28 and GH2328-88 outyielded the two local checks included by the collaborators by 20-27 per cent. These hybrids also out-yielded the normal maize check variety, Abeleehi, by 2936 per cent and the QPM composite variety, Obatanpa, by 12-18 per cent. Mean grain yield over seven locations in four southern African countries ranged from 5000 to $6900 \mathrm{~kg}$ $\mathrm{ha}^{-1}$. The GH132-28 variety was the most outstanding QPM hybrid in this zone. It produced a mean grain yield of $6500 \mathrm{~kg}$
TABLE 3

Grain Yield of Medium-maturing Maize Varieties Tested at 10 Locations* During 1995 and 1996 Major Season

\begin{tabular}{lcccc}
\hline Variety & \multicolumn{2}{c}{ Yield $\left(\mathrm{kg} \mathrm{ha}^{-1}\right)$} & \multicolumn{2}{c}{ Yield $(\%$ Obatanpa) } \\
& 1995 & 1996 & 1995 & 1996 \\
\hline GH110-5 & 7349 & 5175 & 124 & 115 \\
GH132-28 & 6790 & 5316 & 115 & 118 \\
GH110-28 & 6644 & 5311 & 112 & 118 \\
GH2328-88 & 6305 & 5057 & 107 & 112 \\
GH110-88 & 6146 & 4744 & 104 & 105 \\
Obatanpa & 5917 & 4513 & 100 & 100 \\
GH2823-140T & 5784 & 4601 & 98 & 102 \\
Abeleehi & 5701 & 3601 & 96 & 80 \\
EV EJ 105 & 5350 & 3863 & 90 & 86 \\
Local & 4071 & 3119 & 69 & 69 \\
\hline Mean & 6006 & 4530 & & \\
LSD (0.05) & 316 & 250 & & \\
CV (\%) & 16.9 & 16.1 & & \\
\hline
\end{tabular}

Fumesua, Kwadaso, Pokoase, Ohawu, Ejura, Kpeve, Nyankpala, Damongo, Yendi, and Manga

TABLE 4

Grain Yield ( $\left.\mathrm{kg} \mathrm{ha}^{-1}\right)$ of Full Season Maize Varieties Tested During Major Season in 1995 and 1996 at Eight Locations*

\begin{tabular}{lcccc}
\hline Variety & \multicolumn{2}{c}{ Yield $\left(\mathrm{kg}\right.$ ha $\left.{ }^{-1}\right)$} & \multicolumn{2}{c}{ Yield (\% Okomasa) } \\
& 1995 & 1996 & 1995 & 1996 \\
\hline GH132-28 & 6825 & 5624 & 123 & 115 \\
GH110-5 & 6725 & 5281 & 121 & 108 \\
(GH3X1368) X 9701 & 6243 & 5150 & 112 & 106 \\
ENT132H-88 & 6121 & 5235 & 110 & 107 \\
120 DWDMP & 6025 & 4678 & 108 & 96 \\
(GH3X1368) X 5012 & 5962 & 5150 & 107 & 106 \\
(GH20X1368) X 5012 & 5952 & 5108 & 107 & 104 \\
(GH22X1368) X 5012 & 5735 & 4980 & 103 & 102 \\
Okomasa & 5554 & 4880 & 100 & 100 \\
Dobidi & 4905 & 4855 & 88 & 99 \\
8321-18 & 4432 & 4762 & 80 & 98 \\
Local & 4226 & 3451 & 76 & 71 \\
\hline Mean & 5752 & 4900 & & \\
LSD (0.05) & 151 & 278 & & \\
CV (\%) & 16.4 & 16.4 & & \\
\hline
\end{tabular}

* Fumesua, Kwadaso, Pokoase, Ohawu, Ejura, Kpeve, Nyankpala, and Damongo 
TABLE 5

Mean Grain Yield of QPM Hybrids Tested On-farm in Four Agro-ecological Zones in Ghana in 1997

\begin{tabular}{|c|c|c|c|c|c|c|}
\hline \multirow[t]{2}{*}{ Variety } & \multicolumn{5}{|c|}{ Yield $\left(k g h a^{-1}\right)$} & \multirow{2}{*}{$\begin{array}{l}\text { Yield }(\%) \\
\text { Obatanpa }\end{array}$} \\
\hline & $\begin{array}{c}\text { Forest } \\
\text { zone }\end{array}$ & Transition & $\begin{array}{l}\text { Coastal } \\
\text { Savanna }\end{array}$ & $\begin{array}{c}\text { Guinea } \\
\text { Savanna }\end{array}$ & Across & \\
\hline GH110-5 & 4700 & 5661 & 3668 & 6534 & 5147 & 120 \\
\hline GH2328-88 & 4898 & 5252 & 3357 & 5786 & 4941 & 115 \\
\hline GH132-28 & 5013 & 5023 & 2528 & 5473 & 4773 & 112 \\
\hline GH110-28 & 4028 & 5244 & 4282 & 5529 & 4687 & 110 \\
\hline Obatanpa & 4103 & 4785 & 2724 & 5505 & 4280 & 100 \\
\hline GH2328-140T & 3929 & 4306 & 2424 & 4289 & 3937 & 100 \\
\hline Local & 3220 & 4510 & 2236 & 4429 & 3589 & 92 \\
\hline Mean & 4270 & 4969 & 3031 & 5364 & 4479 & \\
\hline LSD (0.05) & 232 & 253 & 285 & 199 & 207 & \\
\hline CV $(\%)$ & 16.8 & 17.1 & 19.6 & 18.3 & 16.4 & \\
\hline
\end{tabular}

TABLE 6

Maturity Ratings, Height, Lodging and Streak Infection of Medium-maturing Varieties Tested at 10 Locations in 1996 Major Season

\begin{tabular}{|c|c|c|c|c|c|}
\hline Variety & $\begin{array}{c}\text { Mid-silk } \\
\text { (days) }\end{array}$ & $\begin{array}{c}\text { Plant } \\
\text { height } \\
(\mathrm{cm})\end{array}$ & $\begin{array}{c}\text { Ear } \\
\text { height } \\
(\mathrm{cm})\end{array}$ & $\begin{array}{c}\text { Grain } \\
\text { moisture } \\
(\%)\end{array}$ & $\begin{array}{c}\text { Total } \\
\text { lodging } \\
(\%)\end{array}$ \\
\hline GH132-28 & 57 & 187 & 83 & 21.1 & 28 \\
\hline GH110-28 & 55 & 176 & 80 & 20.5 & 25 \\
\hline GH110-5 & 53 & 171 & 77 & 20.5 & 33 \\
\hline GH2823-88 & 53 & 185 & 75 & 19.0 & 22 \\
\hline GH110-88 & 52 & 177 & 76 & 19.0 & 24 \\
\hline GH2823-140T & 57 & 185 & 85 & 21.6 & 21 \\
\hline Obatanpa & 55 & 198 & 91 & 19.8 & 29 \\
\hline EV EJ 91 105-DWD & 52 & 169 & 80 & 19.4 & 24 \\
\hline Abeleehi & 55 & 157 & 71 & 19.8 & 22 \\
\hline Local & 58 & 201 & 209 & 19.4 & 33 \\
\hline Mean & 55 & 179 & 83 & 20.0 & 26 \\
\hline LSD (0.05) & 2.7 & 7.4 & 12.7 & 6.9 & 36.0 \\
\hline $\mathrm{CV}(\%)$ & 0.5 & 4 & 4 & 0.4 & 2 \\
\hline
\end{tabular}

ha $^{-1}$ that was not significantly different from those of the local checks. Note that GH132-28 and GH110-5 in particular were as productive as the local checks. Three QPM hybrids GH132-38, GH110-5 and GH2328-88 produced significantly higher grain yield of 10 to 26 per cent than Obatanpa in the region. The GH132-28 variety also out-yielded the normal maize check variety, Abeleehi, by 29 per cent. Mean grain yield over seven locations in three southern American countries ranged from 4000 to $6900 \mathrm{~kg} \mathrm{ha}^{-1}$.

Table 8 shows the overall acceptability scores for maize varieties in 'kenkey' and 'tuo zafi'. The results showed that for 'fante kenkey', the local 
variety was significantly preferred to GH110-5, but was not different from GH2328-88 and GH13228. In 'ga kenkey', no differences were observed in the scores for the hybrids and the local maize variety. However, in 'tuo zafi', the hybrids were preferred to the local maize.

\section{TABLE 7}

Grain Yield of QPM Hybrids Tested in West and Southern Africa and South America in 1995 and 1996

\begin{tabular}{lccc}
\hline Variety & \multicolumn{3}{c}{$\begin{array}{c}\text { Yield }\left(\mathrm{kg} \mathrm{ha}^{-1}\right) \\
\text { South Africa }\end{array}$} \\
\hline GH110-5 & South $_{\text {America }}{ }^{3}$ \\
GH110-88 & 4804 & 5748 & 4958 \\
GH132-28 & 4658 & 5213 & 5008 \\
GH110-28 & 4617 & 6488 & 5379 \\
GH2328-88 & 4545 & 5957 & 5139 \\
Obatanpa & 4181 & 5655 & 6167 \\
GH2823-140T & 4067 & 5140 & 4005 \\
Local Check-2 & 4050 & 5205 & 5291 \\
Local Check-1 & 3812 & 6924 & 6896 \\
Abeleehi & 3751 & 6419 & 6624 \\
\hline Mean & 3535 & 5347 & 5295 \\
No. of sites & 4202 & 5710 & 5376 \\
CV (\%) & 8 & 7 & 6 \\
LSD (0.05) & 16.0 & 14 & 16.4 \\
\hline
\end{tabular}

${ }^{1}$ Benin, Nigeria, Ivory Coast, and Guinea

${ }^{2}$ Zimbabwe, Tanzania, Congo, and South Africa

${ }^{3}$ Brazil, Guatemala, and Mexico

TABLE 8

Overall Acceptability Scores of Maize Varieties in 'Kenkey' and 'Tuo Zafi' Traditional Cereal Foods

\begin{tabular}{lccc}
\hline & \multicolumn{3}{c}{ Overall acceptability* } \\
Maize variety & Fante kenkey & Ga kenkey & Tuo zafi \\
\hline GH 110-5 & $6.20 \mathrm{ab}$ & $5.60 \mathrm{a}$ & $5.87 \mathrm{ab}$ \\
GH 132-28 & $4.87 \mathrm{c}$ & $5.47 \mathrm{a}$ & $6.21 \mathrm{a}$ \\
GH2328-88 & $5.13 \mathrm{c}$ & $5.48 \mathrm{a}$ & $6.14 \mathrm{a}$ \\
Obatanpa & $6.47 \mathrm{a}$ & $5.60 \mathrm{a}$ & $5.50 \mathrm{c}$ \\
NAES EE & $5.13 \mathrm{c}$ & $5.67 \mathrm{a}$ & $5.36 \mathrm{bc}$ \\
Local & $5.53 \mathrm{bc}$ & $6.07 \mathrm{a}$ & $4.93 \mathrm{c}$ \\
Dorke SR & $6.39 \mathrm{a}$ & $5.87 \mathrm{a}$ & - \\
\hline
\end{tabular}

* Overall attributes included taste, texture, and appearance a-c Means on same column with different letters are significantly different $(P<0.05)$

\section{Discussion}

The three hybrids GH132-38, GH110-5 and GH2328-88 are medium-maturing varieties like Obatanpa, the open-pollinated QPM variety. The on-station and on-farm data showed that the hybrids yielded higher than the open-pollinated varieties, irrespective of the maturity period of the later varieties. About 10 per cent yield decrease resulted with the on-farm experiments, indicating that the extent of applying technological package associated with hybrid development is crucial to realizing the full potential of the hybrids. Ghana's QPM varieties have a wide range of adaptation because they performed creditably well in international trials. However, the hybrids differed in their performance in different environments. Nevertheless, they yielded more than open-pollinated varieties and local checks. The hybrids were highly acceptable for preparing traditional foods, although the quality differed with different food preparations.

Ethiopia's maize hybrids yielded between 13-26 per cent (on-station) and 30-55 per cent (on-farm) more than improved released maize varieties (Tolessa et al., 1996). Rattray (1988) reported yield increases of 18 to 60 per cent due to the shift from open-pollinated to hybrid maize varieties. Tattersfield (1982), using data from the commercial farming sector, estimated that between 1946 and 1980 research in Zimbabwe led to increase of up to 325 per cent in maize yield, with hybrid variety technology contributing 45 per cent of the yield improvement. In Ethiopia, the high yield recorded by growing hybrids encouraged farmers to continue growing them, and the demand for hybrid seed and the area under hybrid maize increased substantially. This increase 
in the area for producing hybrid maize was one of the major factors for the bumper harvest of maize in Ethiopia in the 1995-1996 crop season (Tolessa et al., 1996). Although, it is difficult to separate yield improvement due to hybrid technology from that recorded by other disciplines such as extension services, agronomy, plant protection, soil productivity and seed industry, maize hybrid research led to Zimbabwe's revolution in maize yields (Machida, 1996). The technological success with hybrid development in other countries could be repeated in Ghana.

\section{Conclusion}

The QPM hybrids GH132-28, GH110-5 and GH2328-88 developed by Ghana's maize-breeding programming yielded more than open-pollinated varieties and were acceptable in traditional Ghanaian foods. The technological success with QPM hybrid development is expected to lead to a revolution in Ghana's maize production.

\section{REFERENCES}

Badu-Apraku, B., Sallah, P. Y. K. \& TwumasiAfriyie, S. (1991) Recent advances in hybrid maize development and the potential impact of hybrids on the development of the seed industry in Ghana. Paper presented at the Seed Industry Workshop held from 16 to 18th April 1991, University of Science and Technology, Kumasi, Ghana. 13 pp.

GGDP (1996) Annual Report. Ghana Grains Development Project, Crops Research Institute, Kumasi, Ghana. 136 pp.

Lopez-Pereira, M. A. \& Filipello, M. P. (1995) Emerging roles of public and private sectors of maize seed industries in the developing world. CIMMYT Economics Programme Working Paper, pp. 95-101. CIMMYT, Mexico, DF.

Machida, L. (1996) The evolution of hybrid maize breeding in Zimbabwe: Ingredient for the revolution in maize yields. In Maize productivity gains through research and technology dissemination. Proceedings of the Fifth Eastern and Southern Africa Regional Maize Conference (ed. J. K. Ransom, A. F. E. Palmer, B. T. Zambezi, Z. O. Mduruma, S. R. Waddington, K. V. Pixley and D. C. Jewell), Arusha,
Tanzania, 3-7 June 1996. CIMMYT, Addis Ababa, Ethiopia.

Rattray, A. G. H. (1988) Maize breeding and seed production in Zimbabwe up to 1970. In Proceedings of the Eighth South African Maize Breeding Symposium (ed. J. G. Du Press). Department of Agriculture and Water Supply, Pretoria.

Sprague, F. F. \& Dudley, J. W. (1988) Corn and corn improvement. American Society of Agronomy, Inc. USA.

Tattersfield, J. R. (1982) The role of research in increasing food crop potential in Zimbabwe. Zimbabwe Sci. News 16(1), 6-10, 24.

Tolessa, B., Mulatu, K., Wolde, L., Worku, M. \& Tulu, L. (1996) Reflections on the successful achievements of hybrid maize breeding program in Ethiopia. In Maize productivity gains through research and technology dissemination. Proceedings of the Fifth Eastern and Southern Africa Regional Maize Conference (ed. J. K. Ransom, A. F. E. Palmer, B. T. Zambeze, Z. O. Mduruma, S. R. Waddington, K.V. Pixley and D. C. Jewell). Arusha, Tanzania, 3-7 June 1996. CYMMYT, Addis Ababa, Ethiopia.

Twumasi-Afriyie, S. \& P. Y. K. Sallah (1994a) Current maize breeding strategies and achievements in Ghana. In Proceedings of the First National Workshop of Food and Industrial Crops, pp. 7213. Kumasi, Ghana, 25-27 October 1994.

Twumasi-Afriyie, S., Sallah, P. Y. K., FrempongManso, P. P., Ahenkora, K., Haag, W., Agyeman, A. \& Dzah, B. D. (1997) Performance of Ghanaian quality protein maize varieties in international testing in Africa, Asia, Central and South America. Paper presented at the West and Central Africa Regional Workshop, IITA, Coutonou, Benin Republic, 21-25 April 1997.

Twumasi-Afriyie, S., Sallah, P. Y. K., Ahenkora, K., Asiedu, E. A., Obeng-Antwi, K., FrimpongManso, P. P., Osei-Yeboah, S., Apau, A. O., Mensah-Ansah, A., Haag, W. \& Dzah, B. D. (1997) Development and release of three quality protein maize (QPM) hybrid varieties, Dadaba, Mamaba and CIDA-ba, in Ghana. Paper presented to the Ghana's Varietal Release Committee, July 23, 1997. 28 pp.

Twumasi-Afriyie, S., Ahenkora, K., OwusuAkyaw, M. \& Obeng-Antwi, K. (1994b) Progress in quality protein maize improvement in Ghana. Paper presented at the 11th South African Maize 
Breeding Symposium, Pietermarisburg, South Africa, March 15-17, 1994.

Twumasi-Afriyie, S., Sallah, P. Y. K., OwusuAkyaw, M., Ahenkora, K., Soza, R. F., Haag, W., Dzah, B. D., Okai , D. B. \& AkuamoahBoateng, A. (1994c) Development and utilization of quality protein maize in Ghana. Proceedings of the International Symposium on Quality Protein Maize. EMBRAPA, Sete Lagoas, Brazil. 1-3
December 1994.

Twumasi-Afriyie, S., Badu-Apraku, B., Sallah, P. Y. K., Haag, W., Asiedu, E. A., Ahenkora, K., Marfo, K. A., Ohemeng-Dapaah, S. \& Dzah, B. D. (1992) Development and release of Obatanpa, an intermediate maturing quality protein maize variety in Ghana. Paper presented to the GGDP Variety Release Committee, Crops Research Institute, Kumasi. 9 pp. 